\title{
Clinical, Microscopic and Imaging Findings Associated to Mccune-Albright Syndrome: Report of Two Cases
}

\author{
Samuel Porfírio XAVIER ${ }^{1}$ \\ Michel Campos RIBEIRO \\ Luciana Gonçalves SICCHIERI ${ }^{1}$ \\ Luiz Guilherme BRENTEGANI ${ }^{2}$ \\ Suzie Aparecida LACERDA ${ }^{2}$
}

\author{
${ }^{1}$ Department of Oral and Maxillofacial Surgery and Traumatology and Periodontics, \\ Dental School of Ribeirão Preto, University of São Paulo, Ribeirão Preto, SP, Brazil \\ ${ }^{2}$ Department of Morphology, Stomatology and Physiology, Dental School of Ribeirão Preto, \\ University of São Paulo, Ribeirão Preto, SP, Brazil
}

\begin{abstract}
McCune-Albright syndrome is characterized by the triad café-au-lait cutaneous spots, polyostotic fibrous dysplasia and endocrinopathies. This article presents two cases of McCune-Albright syndrome in a middle-aged woman and a young girl. Both patients presented café-au-lait spots on the face and other parts of the body and expansion of the mandible with radiopaque-radiolucent areas with ground-glass radiographic appearance, and were diagnosed as having fibrous dysplasia and endocrine disorders. The patient of Case 1 had fibrous dysplasia on the upper and lower limbs, thorax, face and cranium, early puberty, hyperglycemia, hyperthyroidism and high serum alkaline phosphatase levels. The patient of Case 2 presented lesions on the upper limbs and evident endocrine disorders. In both cases presented in this article, the initial exam was made because of the mandibular lesion. However, a diagnosis of fibrous dysplasia must lead to investigation of the involvement of other bones, characterizing polyostotic fibrous dysplasia, which is manifested in a number of diseases. An accurate differential diagnosis is mandatory to determine the best treatment approach for each case.
\end{abstract}

Key Words: McCune-Albright syndrome, polyostotic fibrous dysplasia, café-au-lait skin hyperpigmentation.

\section{INTRODUCTION}

McCune-Albright syndrome is a rare systemic disease with uncertain prevalence. By counting the number of patients in small closed island communities, it has been estimated that its prevalence may be around 1:30,000 (unpublished data) (1).

The classic manifestation of this syndrome is characterized by the triad café-au-lait cutaneous spots (hyperpigmentation), polyostotic fibrous dysplasia and endocrinopathies (precocious puberty, mainly in girls) $(2,3)$. Recent data suggest that the incidence of cancer (e.g.: bone, breast, thyroid) in adults is increased in patients with this syndrome (4).

The café-au-lait skin pigmentation consists of large hypermelanotic maculae of irregular and serpiginous (coast of Maine) borders, which occur mainly on the front, posterior area of the neck, buttocks, thorax, back, shoulder and pelvis (7). This pigmentation rarely appears on the face, lips and buccal mucosa (8).

Fibrous dysplasia is a benign condition in which normal bone tissue is replaced by fibrous tissue and haphazardly distributed irregular bone trabeculae (5). It may affect either a single bone (monostotic) or multiple bones (polyostotic).

The endocrine disorders associated with this

Correspondence: Profa. Dra. Suzie Aparecida de Lacerda, Departamento de Morfologia, Estomatologia e Fisiologia, Faculdade de Odontologia de Ribeirão Preto, USP, Avenida do Café, s/n, 14040-904 Ribeirão Preto, SP, Brasil. Tel: +55-16-3602-4041. Fax: +55-163633-0999. e-mail: suzie@ forp.usp.br 
disease may include precocious puberty, hyperthyroidism, pituitary adenomas, adrenal primary hyperplasia, hypophosphatemia and ovarian cysts (6).

This article presents two cases of McCune-Albright syndrome, focusing on the description of clinical, radiographic, computed tomographic, histologic and laboratorial findings of this disease, which may allow an early diagnosis and establishment of the best treatment plan to improve function, esthetics and patient's self-esteem.

\section{CASE REPORT}

\section{Case 1}

A 45-year-old Caucasian female patient presented to the Clinic of Surgery of the Dental School of Ribeirão Preto, University of São Paulo, Brazil with a painless tumefaction on the left side of the mandible with facial asymmetry (Fig. 1A).
The patient had history of walking difficulties, pathological fractures of upper and lower limbs with conservative treatment, precocious puberty (onset of menstruation, breast development, and pubic and auxiliary hair development before the age of 8) and early menopause, and presented café-au-lait pigmentation on the back (Fig. 1B).

Intraorally, there was a bone expansion on left mandible, extending from the incisor to the molar region, measuring almost $3 \mathrm{~cm}$ and covered by normal mucosa. Axial computed tomography (CT) scans of the mandible revealed medullar bone enlargement, with mixed density and thin cortical (Fig. 1C). CT and radiographic images showed involvement of upper and lower limbs, thorax, face and skull (Fig. 1D).

The histopathological analysis confirmed fibrous dysplasia consisting of irregular trabeculae of immature bone in cellular fibrous stroma. The bone trabeculae with a curvilinear conformation did not connect to each
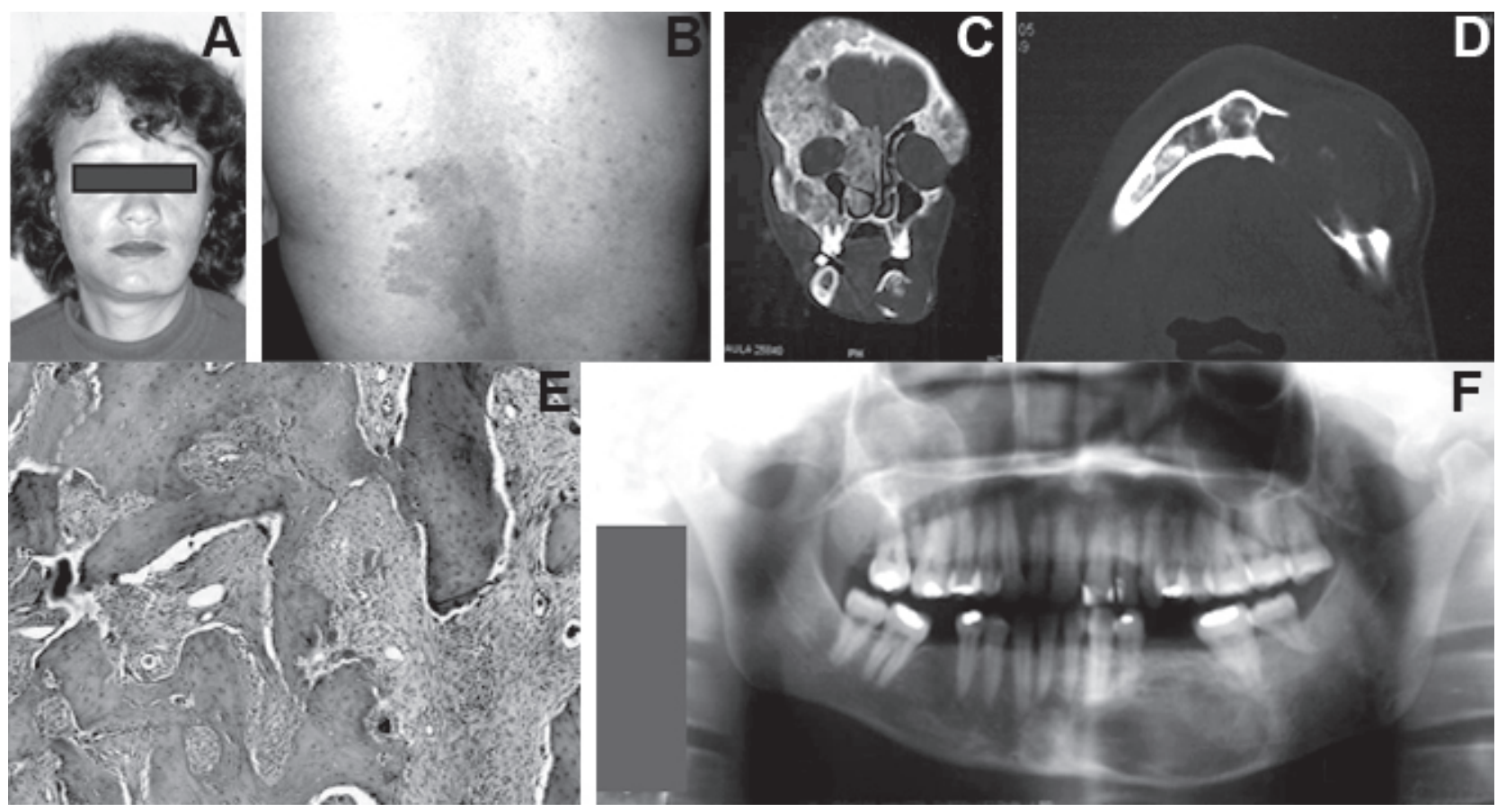

Figure 1. Fibrous dysplasia (FD) and McCune-Albright syndrome (Case 1). A= Facial asymmetry is visible in the left side of the mandible with FD; $\mathrm{B}=$ Typical café-au-lait pigmentation (hypermelanotic maculae) on the patient's back; $\mathrm{C}=\mathrm{CT}$ scan showing lytic alterations of cranial bone; $\mathrm{D}=\mathrm{CT}$ scan of the mandible showing enlargement of medullar bone, and thin cortical; $\mathrm{E}=$ Histological aspect of irregular trabeculae of immature bone in a fibro-cellular stroma with clastic cells surrounding the bone trabeculae and inside bone lacunae; F= Panoramic radiograph showing radiopaque areas with ground-glass appearance, radiolucent areas of mixed density and thinning of the mandibular cortical margin. 
other and were not surrounded by appositional osteoblasts. There was no capsule involving the lesional bone that blended with normal bone. Clastic cells surrounding the bone trabeculae and inside bone lacunae were noted (Fig. 1E). Panoramic radiograph showed radiopaque areas with ground-glass appearance, radiolucent areas of mixed density and thinning of the mandible cortical margin (Fig. 1F), suggestive of fibrous dysplasia.

Hyperglycemia, hyperthyroidism and high serum alkaline phosphatase levels were further detected on laboratory examination.

\section{Case 2}

A 10-year-old Caucasian girl presented to the Clinic of Surgery of the Dental School of Ribeirão Preto, University of São Paulo, Brazil with anterior mandibular tumefaction, causing discreet facial asymmetry.

Intraoral examination revealed an expansive bone lesion extending from the mandibular right 1 st premolar to the mandibular left 1 st premolar, measuring almost 3 $\mathrm{cm}$ and covered by normal mucosa. (Fig. 2A). The patient had café-au-lait spots on the face (Fig. 2B), shoulder and right side of the trunk, and endocrine disorders (precocious onset of menstruation, breast development and auxiliary hair development).CT scans of the mandible for bone tissue showed a hyperdense image, with well-defined limits and a denser peripheral contour (Fig. 2C). The panoramic radiograph revealed a homogeneous radiopaque image, with a ground-glass appearance and radiolucent areas, without defined limits at the anterior mandibular region (Fig. 2D).

Histological examination showed proliferation of cellular fibrous connective tissue with irregular imma-
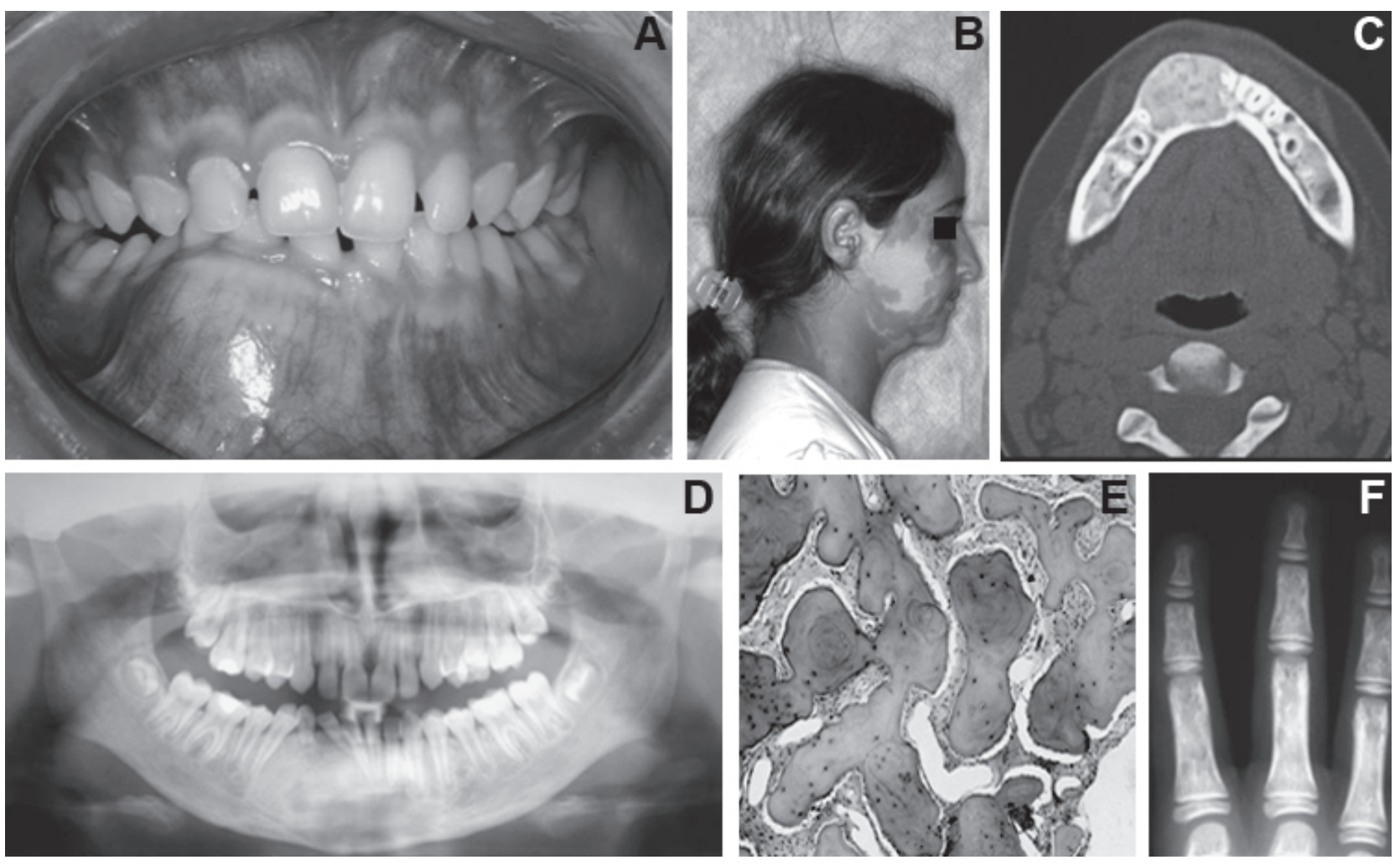

Figure 2. McCune-Albright Syndrome (Case 2). A= Mandibular expansive lesion with discreet facial asymmetry; B=Café-au-lait cutaneous spots on the face; $\mathrm{C}=\mathrm{CT}$ scan showing a well-defined hyperdense image, with a denser peripheral contour; $\mathrm{D}=\mathrm{Panoramic}$ radiograph showing a homogeneous radiopaque with ground-glass appearance, some radiolucent areas with undefined limits in the anterior mandibular region; $\mathrm{E}=$ Histological pattern of fibrous connective stroma with thin, discontinuous curvilinear bone trabeculae; $\mathrm{F}=$ Multiple osteolytic lesions on upper limbs. 
ture bone trabeculae and fibroblasts with spindle-shaped or star-shaped nuclei embedded in compact interlacing collagen stroma, with scattered irregular bone lamellae. The morphology of the bone trabeculae varied from slender "c" shapes to more irregular forms (Fig. 2E). Radiographs of the upper limbs showed multiple lytic lesions (Fig. 2F).

Both patients are under continuous dental-medical surveillance with periodical recalls for control. All procedures described in this paper were performed in accordance with the applicable ethical principles. Patient/parental written informed consent was obtained for report of the cases and disclosure of photographs, $\mathrm{CT}$ scans and radiographs.

\section{DISCUSSION}

The triad café-au-lait cutaneous spots, polyostotic fibrous dysplasia and endocrinopathies characterize McCune Albright syndrome (8). The medical history of the patients may include fractures and deformities of multiple bones, ovarian cysts, renal phosphate wasting and rickets. The most common endocrine disorders are disturbances on sexual hormones (onset of menstruation, breast development, and pubic and axillary hair development before the age of 8 and growth retard), thyroid gland abnormalities (goiter, thyroid nodules, hyperthyroidism), pituitary gland abnormalities (acromegaly, facial deformities, hand/foot enlargement, arthritis, adenoma) and adrenal gland abnormalities (Cushing's disease, weight gain, fragile skin and growth retard).

Both patients described in this paper presented precocious puberty, elevation on serum alkaline phosphatase levels, hyperglycemia and hyperthyroidism, facial asymmetry, enlargement of the mandible, delayed tooth eruption, and tooth displacement, rotation or malformation. Akintoye et al. (3) showed several dental anomalies related to fibrous dysplasia, of unknown origin, and suggested that they resulted from the activation of mutations in tooth development, either directly (hypomineralization or hypoplasia) or indirectly (rotation, displacement, retention of teeth), because of the proximity of abnormal bone. These authors also demonstrated that patients with McCune Albright syndrome can be treated as routine dental patients, but dentists must identify the systemic disorders associated with the disease and be prepared to forward for testing those patients who had not yet been tested.
Polyostotic fibrous dysplasia can affect $75 \%$ of the skeleton. Bone lesions are usually asymptomatic with slow and progressive growth, resulting in asymmetry. Its etiology is not well known, but some studies indicate congenital disorder with an aberrant activity of the bone former mesenchymatous tissue or an interruption of bone maturation in the developmental phase (9). Evidences have suggested that the molecular mechanism responsible for the development of this disease is a genetic mutation that occurs during the embryological phase. This mutation involves the gene that encodes the guanine nucleotide-binding protein (G protein), which is responsible for the binding of receptors to the effector adenyl-cyclase enzyme, resulting in its activation with an excessive production of recurrent AMP and leading to hyperfunction of the target tissue cells $(2,7,10)$. Other mutations have also been reported $(11,5)$.

Polyostotic fibrous dysplasia shares characteristics with several other diseases. An accurate differential diagnosis is thus mandatory to establish a timely and appropriate treatment approach. Differential diagnosis should be made based on clinical, radiographic and histopathologic findings and should include periapical lesions (12), ossifying fibroma, Paget's disease, chronic osteomyelitis (13), neurofibromatosis (8), cherubism, giant cells granuloma, aneurysmal bone cyst, cementoosseous florid dysplasia (14), histiocytosis X, multiple myeloma (15), osteosarcomas, fibrosarcomas and chondrosarcomas (16).

The radiographic aspect of fibrous dysplasia varies depending on the stage of disease progression. In both cases reported hereby, the panoramic radiograph revealed mixed areas and thin bone cortical, with more radiolucent appearance in the older patient. According to Akintoye et al. (17), typical features of fibrous dysplasia, such as a ground-glass pattern with radiolucent, radiopaque or mixed image, can be observed in panoramic radiographs. CT scans show an image of granular aspect delimited by a sclerotic bone. In fibrous dysplasia lesions, CT imaging is of paramount importance to demonstrate the granular texture of the lesional tissue and to determine the extension of the lesion in the craniofacial skeleton. The rarity of McCune-Albright syndrome allied to the heterogeneity of the population poses additional difficulties to the study of this disease and may compromise the establishment of the best treatment.

The typical histopathologic aspect shows irregularly shaped trabeculae of immature bone haphazardly 
distributed in a cellular, loosely fibrous stroma, rich in fibroblasts and collagen fibers. The histological evaluation of the two cases of McCune-Albright syndrome called our attention to the presence of phagocytary giant cells (Fig.1E) around the trabeculae or inside bone lacuna in the older patient. These cells were not found in the younger patient. This observation may explain the tendency to the stabilization of this condition in the adult age (14) because the relationship between decreased estrogenic values and inhibition of the osteoblasts and stimulation of the osteoclasts activity is already known.

There is no specific treatment for McCuneAlbright syndrome, but the patient must have a medical follow-up for the endocrine disturbances. Because of the great variety of lesions in this syndrome, the treatments are almost specific to each patient. In general, the disease is stabilized in the skeletal maturity and, for this reason, surgical interventions can be delayed until the adult age. In some cases, due to accentuated deformity, a precocious surgical removal should be performed providing functional and esthetic improvement (18).

Total surgical resection can be performed in small lesions, but a correct surgical planning must be outlined according to the patient's age, lesion site, presence or absence of functional limitations, and esthetic impairments. Bisphosphonates have been used in the treatment of the syndrome to relieve bone pain and improve lytic lesions $(19,20)$. Calcium, vitamin D and phosphorus supplements may also be useful in some patients (1), but they are still under clinical evaluation.

Individuals with McCune Albright syndrome can be treated as routine dental patients, but dentists must be able to recognize the disease-related systemic disorders in order to forward for investigation subjects that had not yet been tested.

\section{RESUMO}

A Síndrome de McCune-Albright é caracterizada pela tríade manchas café-com-leite na pele, displasia fibrosa poliostótica e endocrinopatias. Este artigo apresenta dois casos de Síndrome de McCune-Albright em uma mulher de meia idade e em uma menina. Ambos apresentavam manchas café-com-leite na face e em outras partes do corpo, expansão da mandíbula com área radiopaca-radiolúcida com aspecto de vidro despolido na radiografia, com o diagnóstico de displasia fibrosa, e desordens endócrinas. O paciente do Caso 1 apresentava displasia fibrosa nos membros inferiores e superiores, tórax, face e crânio, puberdade precoce, hiperglicemia, hipertireoidismo e elevação da fosfatase alcalina no sangue. O paciente do Caso 2 apresentava lesões nos membros superiores e desordem endócrina evidente. Em ambos os casos apresentados neste artigo, o exame inicial foi realizado devido à lesão mandibular. Contudo, o diagnóstico de displasia fibrosa deve conduzir a pesquisa de envolvimento de outros ossos, caracterizando a displasia fibrosa poliostótica, que se manifesta em um grande número de doenças. O diagnóstico diferencial preciso é fundamental para determinar o tratamento adequado a cada caso.

\section{REFERENCES}

1. Chapurlat DR, Orcel P. Fibrous dysplasia of bone and McCuneAlbright syndrome. Best Prac Res Clin Rheumatol 2008;22:55-69.

2. Heller AJ, Dinardo LJ, Massey D. Fibrous dysplasia, chondrosarcoma, and McCune-Albright syndrome. Am J Otolaryngol 2001;22:297-301.

3. Akintoye SO, Lee JS, Feimster T, Booher S, Brahim J, Kingman A, et al. Dental characteristics of fibrous dysplasia and McCune-Albright syndrome. Oral Surg Oral Med Oral Pathol Oral Radiol Endod 2003;96:275-282.

4. Chanson P, Salenave S, Orcel P. McCune-Albright syndrome in adulthood. Pediatr Endocrinol Rev 2007;4:453-462.

5. Riminucci M, Liu B, Corsi A, Shenker A, Spieger AM, Robey PG, et al. The histopathology of fibrous dysplasia of bone in patients with activating mutations of the Gs alpha gene: sitespecific patterns and recurrent histological hallmarks. J Pathol 1999;187:249-258.

6. Collins MT, Chebli C, Jones J, Kushner G, Consugar M, Rinaldo $\mathrm{P}$, et al. Renal phosphate wasting in fibrous dysplasia of bone is part of a generalized renal tubular dysfunction similar to that seen in tumor-induced osteomalacia. J Bone Miner Res 2001;16:806-813.

7. Kumar V, Abba AK, Fausto N. Fibrous and osseous fibrous tumors. In: Robbins and Cotran pathologic basis of disease. Kumar V, Fausto N, Abbas A (Editors). 7th ed. Elsevier, RJ, 2005, p.1359-1361.

8. Gorlin R, Pindborg JJ, Cohen MM. Syndromes of Head and Neck, MacGraw-Hill, New York, 1976.

9. Weinstein LS, Chen M, Liu J. Gs $(\alpha)$ mutations and imprinting defects in human disease. Ann NY Acad Sci 2002;968:173197.

10. Román RR, Johson MC, García BH. McCune-Albright syndrome. Rev Med Chil 2001;129:1365-1372.

11. Levine MA. Clinical implications of genetic defects in $G$ proteins: oncogenic mutations in $G$ alpha $s$ as the molecular basis for the McCune-Albright syndrome. Arch Med Res 1999;30:522-531.

12. Slutzky-Goldberg I, Heling I. Healing of a fibrous dysplastic lesion in a permanent molar after endodontic therapy. J Endod 2007;33:314-317.

13. Saueressig F, Oliveira MG. Polyototic fibrous dysplasia and Mccune-Albright syndrome: case report. Rev Bras Patol Oral 2004;3:70-76.

14. Posnick JC. Fibrous dysplasia of the craniomaxillofacial region: current clinical perspectives. Br J Oral Maxillofac Surg 1998;36:264-273.

15. Stewart JCB. Non Odontogenic benign tumors. In: Oral pathology: clinical pathologic correlations. Regezi JA, Sciuba JJ (Editors). 3rd ed. Philadelphia: WB Saunders Co. 1989. p. 
323-326.

16. Ruggieri P, Sim FH, Bond JR. Osteosarcoma in a patient with polyostotic fibrous dysplasia and Albright's syndrome. Orthop 1995;18:71-75.

17. Akintoye SO, Ottis LL, Atkinson JC, Brahim J, Kushner H, Robey PG, et al. Analyses of variable panoramic radiographic characteristic of maxillo-mandibular fibrous dysplasia in McCune-Albright syndrome. Oral Dis 2004;10:36-43.

18. Rodrigues ED, Bluebond-Langner R, Brazio PBA, Collins M. Near-total mandible reconstruction with a single fibula flap containing fibrous dysplasia in McCune Albright syndrome. J Craniof Surg 2007;18:1479-1482.

19. Chapurlat RD. Medical therapy in adults with fibrous dysplasia of bone. J Bone Miner Res 2006;21:114-119.

20. Plotkin H, Rauch F, Zeitlin L, Munns C, Travers R, Glorieux FH. Effect of pamidronate treatment in children with Polyostotic fibrous dysplasia of bone. J Clin Endocrinol Metab 2003;88:4569-4575.

Accepted April 23, 2008 